\title{
Mapping optimization techniques in project management
}

\author{
Babak Farhang Moghaddam ${ }^{a^{*}}$
}

${ }^{a}$ Institute for Management and Planning Studies, Tehran, Iran

\begin{tabular}{|c|c|}
\hline CHRON I C L E & A B S T R A C T \\
\hline $\begin{array}{l}\text { Article history: } \\
\text { Received: January } 32019 \\
\text { Received in revised format: Jan- } \\
\text { uary } 282019 \\
\text { Accepted: March } 102019 \\
\text { Available online: } \\
\text { March } 102019 \\
\text { Keywords: } \\
\text { Optimization } \\
\text { Project Management } \\
\text { Operations Research }\end{array}$ & $\begin{array}{l}\text { An important function of the project management is to optimize the project in various phases } \\
\text { and at different levels. From sourcing and allocation to scheduling and even dealing with } \\
\text { uncertainties, the science of operation research (OR) has played an important role in this } \\
\text { area. So far, many papers have been published using the optimization science to make vari- } \\
\text { ous decisions regarding the project management. This study aims to investigate all papers } \\
\text { published on the application of optimization in the project management from } 1940 \text { to } 2019 \\
\text { and shows: a) how the trend has changed over this } 79 \text { years period, b) to what direction the } \\
\text { trend has changed, c) determines the interesting topics of the recent years, and d) which } \\
\text { subjects are more attractive as future studies as the applications of the optimization tech- } \\
\text { niques in the project management. }\end{array}$ \\
\hline
\end{tabular}

\section{Introduction}

The increased number of industrial and developmental activities in the form of projects has revealed the importance of using the science of the project management wherein the planning and directing are accomplished in terms of time, cost, and other characteristics such as quality through knowledge, skills, tools, and techniques to meet the needs and expectations of the project stakeholders. To successfully achieve the objectives of each project, a wide range of factors should be aligned for the formation of which the project management knowledge seeks to introduce and strengthen the required skills. According to Scott-Young (2008), the project management will succeed if three dimensions shown in Fig. 1 collaborate and can be implemented, effectively.

Optimization is a tool that helps project managers make optimal decisions such as selecting the most appropriate project from the possible options, determining the best time for the project activities and the level of the overtime work, the rate of ordering and the level of storing materials and equipment, etc. Because of the importance and position of optimization in the project management, two points are worth mentioning: 1) many decisions have key impacts on the project success/failure and their consequences can be irreversible and 2) complicated decisions and the need to consider multiple variables and parameters make the intuitive or manual decisions ineffective.

\footnotetext{
* Corresponding author.

E-mail address: farhang@imps.ac.ir (B. F. Moghaddam) 


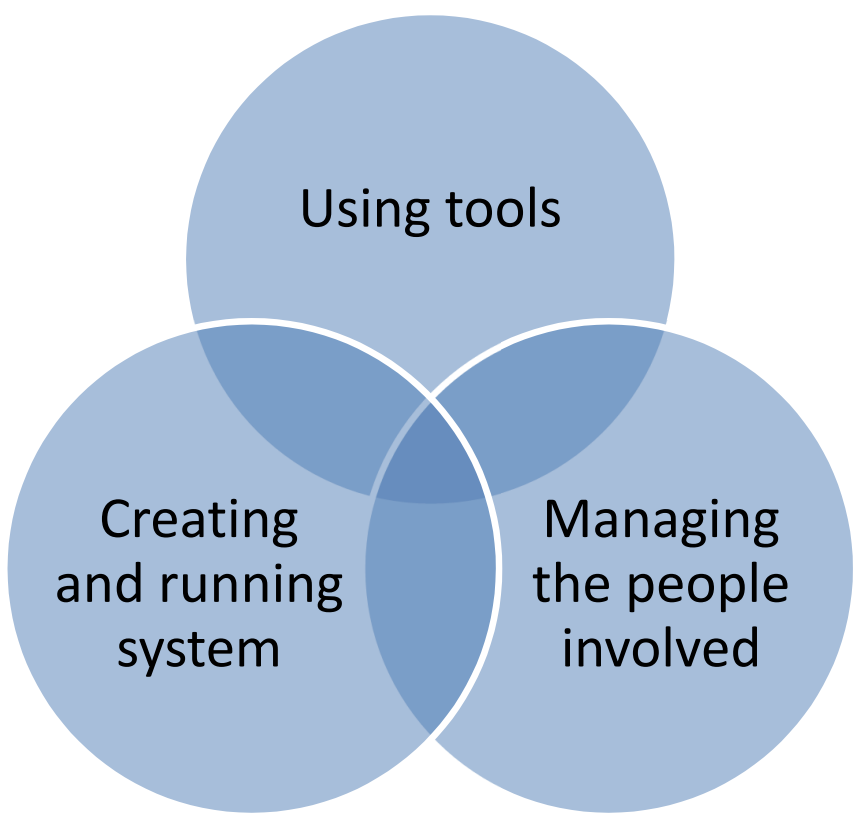

Fig. 1. Dimensions required for the success of the project management (Scott-young, 2008)

\section{Position of optimization problems in different project management areas}

Regarding the project decision making issues, it can be definitely argued that Brucker et al. (1999) presented a very effective paper wherein they assumed the project planning to be analogous to the single-/multi-product production planning to which limited resources were allocated using the optimization tool. They then developed the idea to propose a comprehensive project planning model through a resource categorization and allocation scheme capable of being used in different sectors of the industries to control projects. Numerous references to this paper reveal that the authors have reached their goal of presenting a comprehensive model used widely in all industries. Presenting a single notation in this regard is another goal they have explicitly set in their paper and have reached it to a large extent. They have also made an effort to examine, present, and explain appropriate, precise, and heuristic solution methods based on the type and properties of each model presented in the paper. Another high-reference related paper belongs to Herroelen (2005) wherein he precisely stated that the main problem is to plan the project activities by considering resource limitations and other constraints. He specified that despite all the efforts made, numerous reports show that many projects have exceeded their planned time and budget, and many planning methods still need to find a practical way to prevent this problem. Aiming at facing the project planning theory and process, he presented a general and hierarchical plan and control framework wherein he considered various planning situations and discussed important research opportunities for the exploration of which can narrow the theory-practice gap. In a paper published by Tavares (2002), the role of optimization models in the project management was studied through reviewing and grouping the important papers published until then. This grouping is limited and involves the following:

1- Modeling the network of the project activities (scheduling and sequencing)

2- Resource allocation methods

\section{3- Project evaluation methods}

A review of the paper publication trend in each of these three areas provides interesting information on their attractiveness for researchers and their research needs. Fig. 2 reviews the related papers published during 2000-2019 and shows that the scheduling and sequencing of activities is far more interesting than the other two areas; in the year 2000, the number of papers in this area has been more than 110 among which more than 75 are published in 2018. 


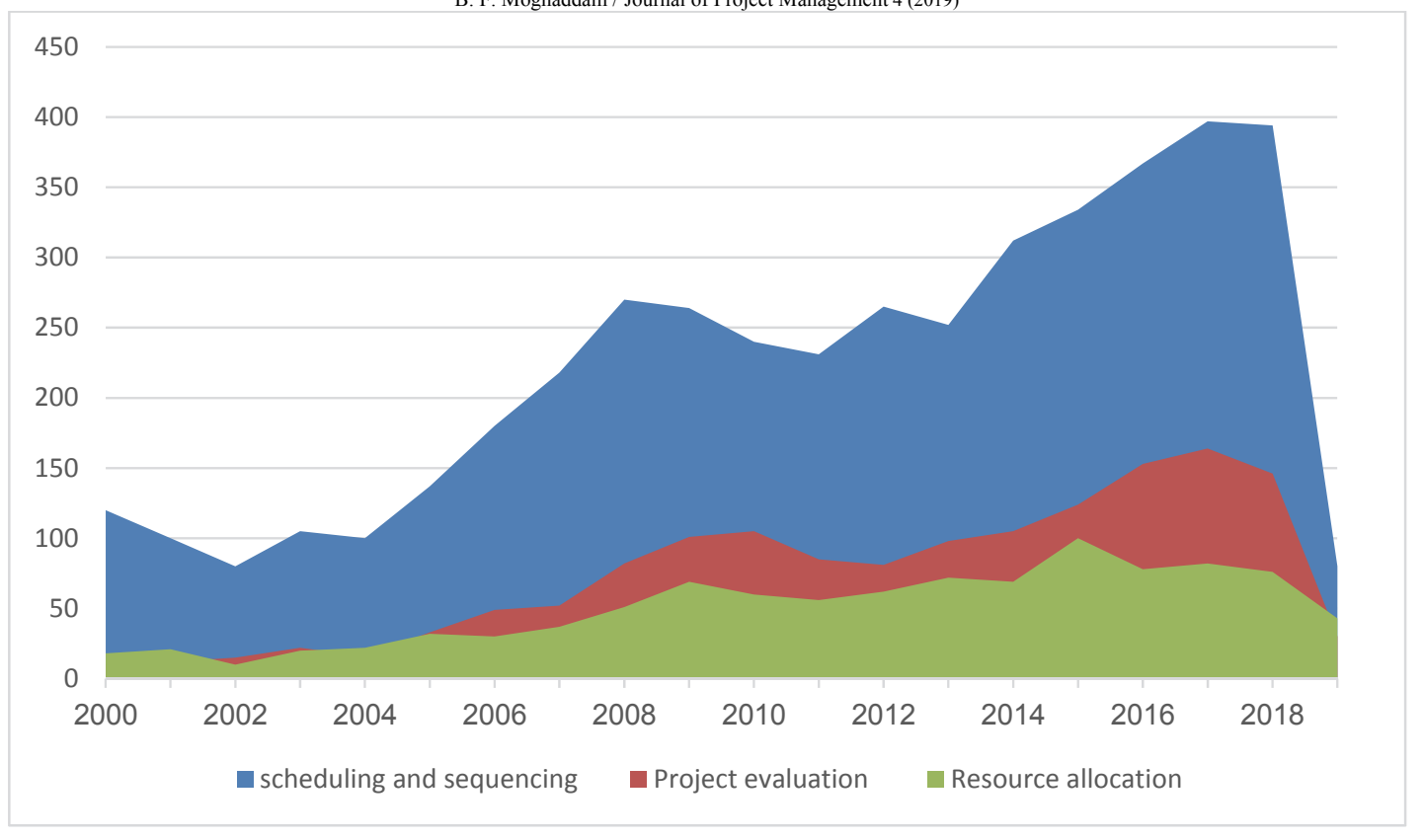

Fig. 2. Related papers published during 2000-2019

Another point concluded from Fig. 2 is the similar rising and falling trend in the number of the papers in the three areas; 2008 shows a considerable growth while 2009 shows an almost identical decline. This means that, regardless of the grouping of different project management areas, the number of the published papers has had an appropriate growth and shows a clear horizon in this area. Table 1 shows the most cited paper in each field. If different users of the project control issue are to be studied from a specialized point of view, it would suffice to check the related papers' publication sources. Fig. 3 shows the number of papers published by major journals in this area. Rankings 2, 3, 9, 11, and 14 of these journals belong to the construction specialized area and other rankings belong to specialized journals of the industrial engineering, especially OR. This means that the optimization look in the project management science has found its acceptable place in other specialized fields as well.



Fig. 3. Most relevent sources 
Table 1

Total citation of each feild

\begin{tabular}{|c|c|c|c|c|c|c|c|c|c|c|c|}
\hline No. & Articles & 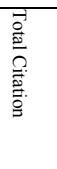 & 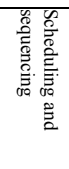 &  & 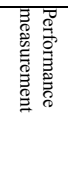 & No. & Articles & 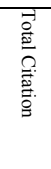 & 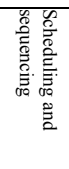 & 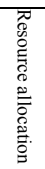 & 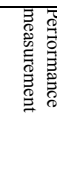 \\
\hline 1 & (BRUCKER P, 1999) & 734 & $\sqrt{ }$ & & & 67 & (SCOTT-YOUNG C, 2008) & 67 & $\sqrt{ }$ & & \\
\hline 2 & (HERROELEN W, 2005) & 409 & $\sqrt{ }$ & $\sqrt{ }$ & & 68 & (WANG M, 2003) & 67 & $\sqrt{ }$ & & \\
\hline 3 & (KOLISCH R, 2006) & 356 & $\sqrt{ }$ & & & 69 & (GHASEMZADEH F, 1999) & 66 & $\sqrt{ }$ & & \\
\hline 4 & (HARTMANN S, 2010) & 329 & & $\sqrt{ }$ & $\sqrt{ }$ & 70 & (KLEIN R, 1999) & 66 & & $\sqrt{ }$ & \\
\hline 5 & (MERKLE D, 2002) & 329 & & $\sqrt{ }$ & & 71 & (HERROELEN W, 2004) & 65 & & & $\sqrt{ }$ \\
\hline 6 & (KELLER RT, 2001) & 293 & & $\sqrt{ }$ & & 72 & (WANG W, 2014) & 64 & $\sqrt{ }$ & & \\
\hline 7 & (HARTMANN S, 2000) & 263 & $\sqrt{ }$ & & & 73 & (KONE O, 2011) & 64 & & $\sqrt{ }$ & \\
\hline 8 & (BOULEIMEN K, 2003) & 261 & $\sqrt{ }$ & & & 74 & (BROWNING TR, 2010) & 64 & $\sqrt{ }$ & & \\
\hline 9 & (HOEGL M, 2004) & 233 & $\sqrt{ }$ & & & 75 & (VALLS V, 2009) & 64 & $\sqrt{ }$ & & \\
\hline 10 & (CHUA DKH, 2003) & 228 & $\sqrt{ }$ & & & 76 & (ZHANG H, 2006) & 63 & & $\sqrt{ }$ & \\
\hline 11 & (HUCHZERMEIER A, 2001) & 225 & & $\sqrt{ }$ & & 77 & (GUTJAHR WJ, 2000) & 63 & $\sqrt{ }$ & & \\
\hline 12 & (KOLISCH R, 2001) & 209 & $\sqrt{ }$ & & & 78 & (COELHO J, 2011) & 62 & & & $\sqrt{ }$ \\
\hline 13 & (KELLER RT, 2006) & 205 & & $\sqrt{ }$ & $\sqrt{ }$ & 79 & (HEIMERL C, 2010) & 62 & & $\sqrt{ }$ & \\
\hline 14 & (PULLEY JM, 2012) & 189 & $\sqrt{ }$ & & $\sqrt{ }$ & 80 & (KIM KW, 2005) & 62 & & & $\sqrt{ }$ \\
\hline 15 & (CONIGRAVE KM, 2002) & 187 & $\sqrt{ }$ & $\sqrt{ }$ & & 81 & (HEGAZY T, 2001) & 62 & $\sqrt{ }$ & & \\
\hline 16 & (KEIL M, 2000) & 176 & $\sqrt{ }$ & & & 82 & (GHODDOUSI P, 2013) & 61 & & & $\sqrt{ }$ \\
\hline 17 & (CHO SH, 2005) & 173 & $\sqrt{ }$ & & $\sqrt{ }$ & 83 & (ZIARATI K, 2011) & 61 & & $\sqrt{ }$ & \\
\hline 18 & (BONNER JM, 2002) & 173 & $\sqrt{ }$ & & & 84 & (LAMBRECHTS O, 2011) & 61 & & & $\sqrt{ }$ \\
\hline 19 & (DEBELS D, 2006) & 169 & & $\sqrt{ }$ & & 85 & (VANHOUCKE M, 2001) & 60 & & $\sqrt{ }$ & \\
\hline 20 & (LOVE PED, 2002) & 164 & & & $\sqrt{ }$ & 86 & (BENDOLY E, 2007) & 60 & $\sqrt{ }$ & & \\
\hline 21 & (DREZET LE, 2008) & 162 & & $\sqrt{ }$ & & 87 & (LOVE PED, 2012) & 60 & $\sqrt{ }$ & & $\sqrt{ }$ \\
\hline 22 & (JARBOUI B, 2008) & 158 & & $\sqrt{ }$ & & 88 & (AGARWAL A, 2011) & 59 & $\sqrt{ }$ & & \\
\hline 23 & (GALLOWAY PD, 2006) & 150 & $\sqrt{ }$ & & & 89 & (GUTJAHR WJ, 2008) & 59 & $\sqrt{ }$ & $\sqrt{ }$ & $\sqrt{ }$ \\
\hline 24 & (HARTMANN S, 2002) & 143 & & $\sqrt{ }$ & $\sqrt{ }$ & 90 & (ZHU G, 2005) & 59 & $\sqrt{ }$ & $\sqrt{ }$ & \\
\hline 25 & (ROPPONEN J, 2000) & 140 & $\sqrt{ }$ & & & 91 & (PENA-MORA F, 2001) & 59 & $\sqrt{ }$ & $\sqrt{ }$ & \\
\hline 26 & (HARTMANN S, 2001) & 139 & $\sqrt{ }$ & & & 92 & (DORNDORF U, 2000) & 59 & & $\sqrt{ }$ & \\
\hline 27 & (ALCARAZ J, 2001) & 134 & & $\sqrt{ }$ & & 93 & (PARK M, 2003) & 58 & $\sqrt{ }$ & & \\
\hline 28 & (LINBERG KR, 1999) & 131 & & & $\sqrt{ }$ & 94 & (VIANA A, 2000) & 57 & & & $\sqrt{ }$ \\
\hline 29 & (HERROELEN W, 2004) & 126 & & $\sqrt{ }$ & & 95 & (NEUMANN K, 1999) & 57 & & $\sqrt{ }$ & \\
\hline 30 & (JERGEAS G, 2001) & 126 & & $\sqrt{ }$ & & 96 & (HOEGL M, 2003) & 56 & $\sqrt{ }$ & & \\
\hline 31 & (WEGLARZ J, 2011) & 122 & & $\sqrt{ }$ & & 97 & (SCHWINDT C, 2006) & 56 & & $\sqrt{ }$ & \\
\hline 32 & (KALIBA C, 2009) & 122 & & $\sqrt{ }$ & & 98 & (LOVE PED, 2015) & 55 & $\sqrt{ }$ & & \\
\hline 33 & (GONCALVES JF, 2008) & 119 & $\sqrt{ }$ & & & 99 & (LUU VT, 2009) & 55 & & & $\sqrt{ }$ \\
\hline 34 & (ALBA E, 2007) & 118 & & $\sqrt{ }$ & & 100 & (LOVE PED, 2008) & 55 & & $\sqrt{ }$ & \\
\hline 35 & (MENDES JJM, 2009) & 117 & $\sqrt{ }$ & & & 101 & (BARRAZA GA, 2004) & 55 & & $\sqrt{ }$ & \\
\hline 36 & (ALCARAZ J, 2003) & 117 & $\sqrt{ }$ & & $\sqrt{ }$ & 102 & (ELLOUMI S, 2010) & 54 & & & $\sqrt{ }$ \\
\hline 37 & (HOEGL M, 2005) & 116 & & & $\sqrt{ }$ & 103 & (LIU SS, 2008) & 54 & $\sqrt{ }$ & & $\sqrt{ }$ \\
\hline 38 & (ZHANG S, 2015) & 112 & & $\sqrt{ }$ & & 104 & (ELAZOUNI AM, 2007) & 54 & & $\sqrt{ }$ & \\
\hline 39 & (VALLS V, 2008) & 109 & $\sqrt{ }$ & $\sqrt{ }$ & & 105 & (SMITH HJ, 2003) & 54 & $\sqrt{ }$ & & \\
\hline 40 & (AL-FAWZAN MA, 2005) & 109 & & $\sqrt{ }$ & $\sqrt{ }$ & 106 & (KUO SF, 2000) & 54 & & $\sqrt{ }$ & \\
\hline 41 & (LEE E, 2009) & 107 & & & $\sqrt{ }$ & 107 & (NITITHAMYONG P, 2006) & 53 & & $\sqrt{ }$ & \\
\hline 42 & (MCKOY JM, 2007) & 107 & & $\sqrt{ }$ & & 108 & (HYARI K, 2006) & 53 & & $\sqrt{ }$ & \\
\hline 43 & (ARTIGUES C, 2003) & 106 & & & $\sqrt{ }$ & 109 & (KE H, 2005) & 53 & $\sqrt{ }$ & & \\
\hline 44 & (Yamashita D, 2006) & 104 & $\sqrt{ }$ & & & 110 & (ABDEL-HAMID TK, 1999) & 53 & & $\sqrt{ }$ & \\
\hline 45 & (CESTA A, 2002) & 102 & & $\sqrt{ }$ & & 111 & (CHANG CK, 2008) & 52 & $\sqrt{ }$ & & \\
\hline 46 & (YANG LR, 2012) & 101 & $\sqrt{ }$ & & & 112 & (LIBERATORE MJ, 2001) & 52 & & $\sqrt{ }$ & \\
\hline 47 & (HOEGL M, 2007) & 99 & & $\sqrt{ }$ & $\sqrt{ }$ & 113 & (KLEIN R, 2000) & 52 & $\sqrt{ }$ & & \\
\hline 48 & (LYNEIS JM, 2001) & 99 & & $\sqrt{ }$ & $\sqrt{ }$ & 114 & (HWANG BG, 2014) & 51 & $\sqrt{ }$ & & \\
\hline 49 & (MOHRING RH, 2003) & 98 & & $\sqrt{ }$ & $\sqrt{ }$ & 115 & (POPOV V, 2010) & 51 & & $\sqrt{ }$ & \\
\hline 50 & (MIKA M, 2005) & 96 & & $\sqrt{ }$ & & 116 & (VANHOUCKE M, 2007) & 51 & & $\sqrt{ }$ & \\
\hline 51 & (TORMOS P, 2001) & 94 & $\sqrt{ }$ & & & 117 & (CHANG CK, 2001) & 51 & $\sqrt{ }$ & & \\
\hline 52 & (LIPKE W, 2009) & 92 & & $\sqrt{ }$ & & 118 & (KARIM A, 1999) & 51 & $\sqrt{ }$ & & \\
\hline 53 & (LOVA A, 2001) & 89 & & $\sqrt{ }$ & & 119 & (LOVE PED, 2009) & 50 & & $\sqrt{ }$ & \\
\hline 54 & (VAN DE VONDER S, 2005) & 89 & & $\sqrt{ }$ & & 120 & (ULUSOY G, 2001) & 50 & & $\sqrt{ }$ & \\
\hline 55 & (SENOUCI AB, 2001) & 81 & $\sqrt{ }$ & & $\sqrt{ }$ & 121 & (WANG H, 2004) & 49 & & $\sqrt{ }$ & \\
\hline 56 & (NEUMANN K, 2000) & 80 & $\sqrt{ }$ & & & 122 & (CHEN WN, 2010) & 49 & $\sqrt{ }$ & $\sqrt{ }$ & $\sqrt{ }$ \\
\hline 57 & (BACCARINI D, 2004) & 79 & $\sqrt{ }$ & $\sqrt{ }$ & & 123 & (CHEN JQ, 2009) & 49 & & $\sqrt{ }$ & \\
\hline 58 & (IBBS CW, 2001) & 75 & $\sqrt{ }$ & & & 124 & (CHOI J, 2004) & 49 & & $\sqrt{ }$ & \\
\hline 59 & (LEVARDY V, 2009) & 72 & $\sqrt{ }$ & & & 125 & $(\mathrm{ZHAO} \sqrt{\mathrm{B}}, 2016)$ & 48 & & $\sqrt{ }$ & \\
\hline 60 & (WANG J, 2009) & 72 & & $\sqrt{ }$ & & 126 & (GEORGY ME, 2008) & 48 & & & $\sqrt{ }$ \\
\hline 61 & (HERROELEN W, 2005) & 71 & & $\sqrt{ }$ & & 127 & (VAN DE VONDER S, 2007) & 48 & & $\sqrt{ }$ & \\
\hline 62 & (AHSAN K, 2010) & 70 & $\sqrt{ }$ & & & 128 & (NA KS, 2007) & 48 & $\sqrt{ }$ & & \\
\hline 63 & (HEILMANN R, 2003) & 70 & & & $\sqrt{ }$ & 129 & (KOULINAS G, 2013) & 47 & $\sqrt{ }$ & $\sqrt{ }$ & \\
\hline 64 & (CHEN W, 2010) & 69 & $\sqrt{ }$ & & & 130 & (KE H, 2010) & 46 & & & $\sqrt{ }$ \\
\hline 65 & (NIGHTINGALE P, 2000) & 69 & $\sqrt{ }$ & & & 131 & (SOBEL MJ, 2009) & 46 & & & $\sqrt{ }$ \\
\hline 66 & (CHANG AST, 2002) & 68 & $\sqrt{ }$ & & & 132 & (BALLESTIN F, 2007) & 46 & & $\sqrt{ }$ & \\
\hline
\end{tabular}


If the most frequently used words of each project management branch are examined, the word "evaluation" ranks first in the performance evaluation; general terms dominate in other two areas. Table 2 indicates how close the most frequent words in these three areas are.

Table 2

Most frequent words

\begin{tabular}{|c|c|c|c|c|c|}
\hline \multicolumn{2}{|c|}{ Scheduling } & \multicolumn{2}{|c|}{ allocation } & \multicolumn{2}{|c|}{ performance } \\
\hline Word & Occurrence & Word & Occurrence & Word & Occurrence \\
\hline management & 334 & management & 113 & performance & 401 \\
\hline model & 315 & model & 100 & model & 129 \\
\hline genetic algorithm & 269 & allocation & 96 & success & 121 \\
\hline optimization & 254 & resource-allocation & 68 & impact & 77 \\
\hline algorithm & 246 & optimization & 66 & framework & 76 \\
\hline performance & 189 & performance & 57 & design & 70 \\
\hline heuristics & 171 & algorithm & 51 & perspective & 66 \\
\hline construction & 155 & genetic algorithm & 44 & product development & 66 \\
\hline networks & 147 & selection & 36 & innovation & 62 \\
\hline classification & 145 & systems & 35 & systems & 59 \\
\hline search & 117 & product development & 33 & construction & 53 \\
\hline time & 114 & heuristics & 30 & organizations & 50 \\
\hline system & 112 & uncertainty & 26 & knowledge & 44 \\
\hline branch & 108 & construction & 25 & uncertainty & 42 \\
\hline uncertainty & 99 & framework & 24 & implementation & 41 \\
\hline design & 97 & information & 24 & industry & 37 \\
\hline scheduling problem & 89 & classification & 23 & technology & 37 \\
\hline
\end{tabular}

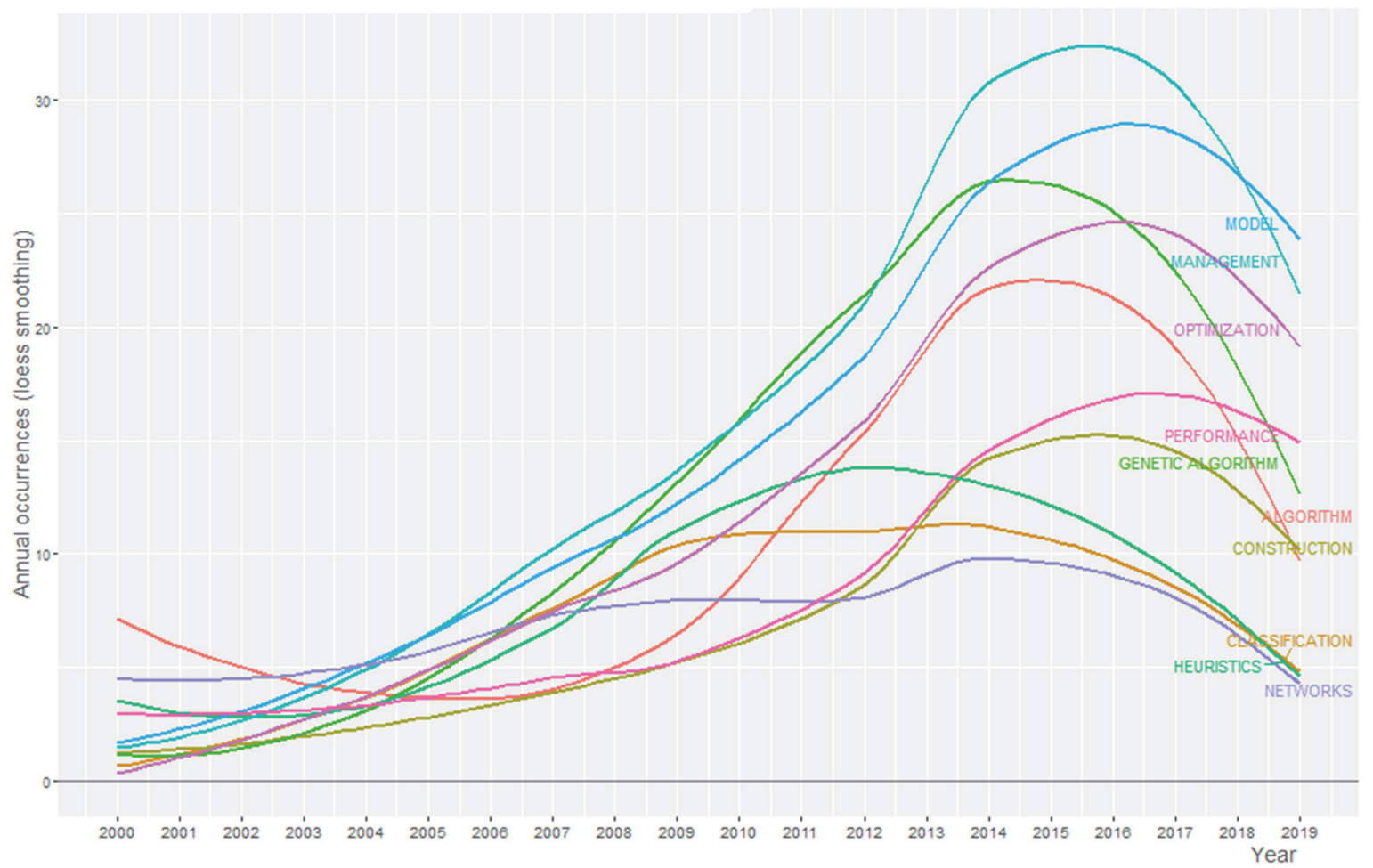

Fig. 4. Word growth

A careful study of the words repeatedly used in papers during the past twenty years shows that the modeling through OR (as a very efficient and effective tool) has found a special place in the project management science. Modeling and optimization in Fig. 4 did not have a specific place in the mentioned science in the late $20^{\text {th }}$ and early $21^{\text {st }}$ centuries; they began their growth in the first decade of the $21^{\text {st }}$ century. This suggests that the project management science has entered a larger scale domain with half a century delay compared with the construction management. Fig. 4 also shows that the concept of evaluation has not yet found its real place and it can be foreseen that there will be a 
fast growth in this area in the coming few decades and many researchers will work on it. If the scope of the words used in this science is examined systematically, it will be found that there are significant internal effects among words in the three areas. Fig. 5 shows that the project network has been formed mostly through algorithms and mathematical models and the most specific case considered in the models has been the parametric uncertainty which is a very important factor in the project failure and success; hence, it has attracted more attention. On the other hand, "design" and "modeling" are the keywords that play a role in the evaluation and show the role of optimization in this aspect of the project management.

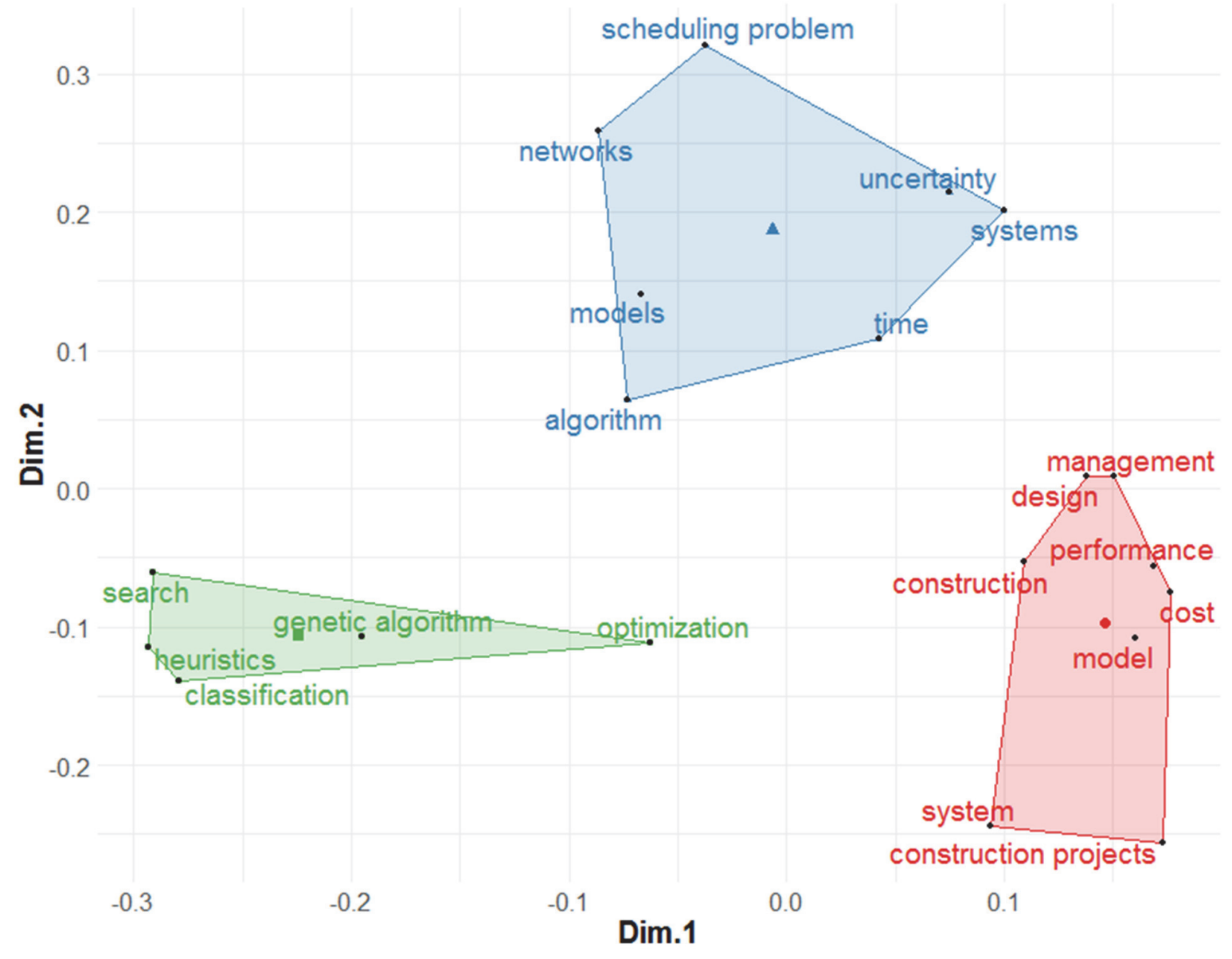

Fig. 5. Conceptual structure map

\section{Conclusions}

The effort made in this paper has aimed to study and analyze different phases of the application of optimization in the project management using a scientific approach. Accordingly, all papers published during the period 1940-2019 to answer the project management-related questions with the optimization tool were reviewed and the results have shown that the optimization science has penetrated so deep in this area that other specialized disciplines (not generally familiar with it) should also use it to advance their research objectives. On the other hand, different parts considered more by authors were identified and grouped into three areas of scheduling and sequencing activities, resource allocation, and performance evaluation. Although various issues were raised and investigated in all the three areas, the scheduling and sequencing activities area was known to be more interesting and applicable than the other two. A study of different graphs also shows the emergence of new and growing areas a very important and interesting of which is the use of optimization in the evaluation of the project performance. 


\section{References}

Abdel-Hamid, T., Sengupta, K., \& Swett, C. (1999, 12). The impact of goals on software project management: An experimental investigation. MIS Quaterly, 23(4), 531-555.

Agarwal, A., Colak, S., \& Erenguc, S. $(2011,1)$. A Neurogenetic approach for the resource-constrained project scheduling problem. Computers \& Operations Research, 38(1, SI), 44-50.

Ahsan, K., \& Gunawan, I. (2010, 1). Analysis of cost and schedule performance of international development projects. International Journal of Project Management, 28(1), 68-78.

Alba, E., \& Chicano, J. (2007, 6). Software project management with GAs. Information Sciences, 177(11), 2380-2401.

Alcaraz, J., \& Maroto, C. (2001). A robust genetic algorithm for resource allocation in project scheduling. Annals of Operations Research, 102(1-4), 83-109.

Alcaraz, J., Maroto, C., \& Ruiz, R. (2003, 6). Solving the multi-mode resource-constrained project scheduling problem with genetic algorithms. Journal of the Operational Research Society, 54(6), 614626.

Al-Fawzan, M., \& Haouari, M. (2005, 5). A bi-objective model for robust resource-constrained project scheduling. International Journal of Production Economics, 96(2), 175-187.

Artigues, C., Michelon, P., \& Reusser, S. (2003). Insertion techniques for static and dynamic resourceconstrained project scheduling. European Journal of Operational Research, 149(2), 249-267.

Arrow, K. J., Cropper, M. L., Gollier, C., Groom, B., Heal, G. M., Newell, R. G., ... \& Sterner, T. (2014). Should governments use a declining discount rate in project analysis?. Review of Environmental Economics and Policy, 8(2), 145-163.

Baccarini, D., Salm, G., \& Love, P. (2004). Management of risks in information technology projects. Industrial Management \& Data Systems, 104(3-4), 286-295.

Ballestin, F. (2007, 6). When it is worthwhile to work with the stochastic RCPSP? Journal of Scheduling, 10(3), 153-166.

Barraza, G., Back, W., \& Mata, F. (2004, 1). Probabilistic forecasting of project performance using stochastic S curves. Journal of Construction Engineering and Management-ASCE, 130(1), 25-32.

Bendoly, E., \& Swink, M. (2007, 4). Moderating effects of information access on project management behavior, performance and perceptions. Journal of Operations Management, 25(3), 604-622.

Bonner, J., Ruekert, R., \& Walker, O. (2002, 5). Upper management control of new product development projects and project performance. Journal of Product Innovation Management, 19(3), 233-245.

Bouleimen, K. L. E. I. N., \& Lecocq, H. O. U. S. N. I. (2003). A new efficient simulated annealing algorithm for the resource-constrained project scheduling problem and its multiple mode version. European Journal of Operational Research, 149(2), 268-281.

Browning, T., \& Yassine, A. (2010, 8). Resource-constrained multi-project scheduling: Priority rule performance revisited. International Journal of Production Economics, 126(2), 212-228.

Brucker, P., Drexl, A., Mohring, R., Neumann, K., \& Pesch, E. (1999, 1). Resource-constrained project scheduling: Notation, classification, models, and methods. European Journal of Operational Research, 112(1), 3-41.

Brucker, P., \& Knust, S. (2003). Lower bounds for resource-constrained project scheduling problems. European Journal of Operational Research, 149(2), 302-313.

Cesta, A., Oddi, A., \& Smith, S. F. (2002). A constraint-based method for project scheduling with time windows. Journal of Heuristics, 8(1), 109-136.

Chang, A. (2002, 1). Reasons for cost and schedule increase for engineering design projects. Journal of Management in Engineering, 18(1), 29-36.

Chang, C., Christensen, M., \& Zhang, T. (2001). Genetic algorithms for project management. Annals of Software Engineering, 11, 107-139.

Chang, C., Jiang, H.-y., Di, Y., Zhu, D., \& Ge, Y. (2008, 10). Time-line based model for software project scheduling with genetic algorithms. Information and Software Technology, 50(11), 1142-1154.

Chen, J., \& Askin, R. (2009, 2). Project selection, scheduling and resource allocation with time dependent returns. European Journal of Operational Research, 193(1), 23-34.

Chen, W., Shi, Y.-j., Teng, H.-f., Lan, X.-p., \& Hu, L.-c. (2010, 3). An efficient hybrid algorithm for resource-constrained project scheduling. Information Sciences, 180(6, SI), 1031-1039.

Chen, W.-N., Zhang, J., Chung, H.-H., Huang, R.-Z., \& Liu, O. (2010, 1). Optimizing Discounted Cash Flows in Project Scheduling-An Ant Colony Optimization Approach. IEEE Transactions on Systems Man and Cybernetics Part C-Applicationa and Reviews, 40(1), 64-77. 
Cho, S., \& Eppinger, S. (2005, 8). A simulation-based process model for managing complex design projects. IEEE Transactions on Engineering Management, 52(3), 316-328.

Coelho, J., \& Vanhoucke, M. (2011). Multi-mode resource-constrained project scheduling using RCPSP and SAT solvers. European Journal of Operational Research, 213(1), 73-82.

Choi, J., Realff, M., \& Lee, J. $(2004,6)$. Dynamic programming in a heuristically confined state space: a stochastic resource-constrained project scheduling application. Computers \& Chemical Engineering, 28(6-7), 1039-1058.

Chua, D., Tyagi, A., Ling, S., \& Bok, S. (2003, 11). Process-parameter-interface model for design management. Journal of Construction Engineering and Management-ASCE, 129(6), 653-663.

Conigrave, K. M., Degenhardt, L. J., Whitfield, J. B., Saunders, J. B., Helander, A., \& Tabakoff, B. (2002). CDT, GGT, and AST as markers of alcohol use: the WHO/ISBRA collaborative project. Alcoholism: Clinical and Experimental Research, 26(3), 332-339.

Debels, D., De Reyck, B., Leus, R., \& Vanhoucke, M. (2006). A hybrid scatter search/electromagnetism meta-heuristic for project scheduling. European Journal of Operational Research, 169(2), 638-653.

De Reyck, B., \& Herroelen, W. $(1999,12)$. The multi-mode resource-constrained project scheduling problem with generalized precedence relations. European Journal of Operational Research, 119(2), 538-556.

de Vonder, S., Demeulemeester, E., \& Herroelen, W. (2007, 6). A classification of predictive-reactive project scheduling procedures. Journal of Scheduling, 10(3), 195-207.

de Vonder, S., Demeulemeester, E., Herroelen, W., \& Leus, R. $(2005,8)$. The use of buffers in project management: The trade-off between stability and makespan. International Journal of Production Economics, 97(2), 227-240.

Dorndorf, U., Pesch, E., \& Phan-Huy, T. (2000). A branch-and-bound algorithm for the resource-constrained project scheduling problem. Mathematical Methods of Operations Research, 52(3), 413-439.

Drezet, L. E., \& Billaut, J. C. (2008). A project scheduling problem with labour constraints and timedependent activities requirements. International Journal of Production Economics, 112(1), 217-225.

Elazouni, A., \& Metwally, F. (2007, 1). Expanding finance-based scheduling to devise overall-optimized project schedules. Journal of Construction Engineering and Management-ASCE, 133(1), 86-90.

Elloumi, S., \& Fortemps, P. (2010). A hybrid rank-based evolutionary algorithm applied to multi-mode resource-constrained project scheduling problem. European Journal of Operational Research, 205(1), $31-41$.

Galloway, P. D. (2006). Survey of the construction industry relative to the use of CPM scheduling for construction projects. Journal of construction engineering and management, 132(7), 697-711.

Georgy, M. (2008, 7). Evolutionary resource scheduler for linear projects. Automation in Construction, 17(5), 573-583.

Ghasemzadeh, F., Archer, N., \& Iyogun, P. (1999, 7). A zero-one model for project portfolio selection and scheduling. Journal of the Operational Research Society, 50(7), 745-755.

Ghoddousi, P., Eshtehardian, E., Jooybanpour, S., \& Javanmardi, A. (2013, 3). Multi-mode resourceconstrained discrete time-cost-resource optimization in project scheduling using non-dominated sorting genetic algorithm. Automation in Construction, 30, 216-227.

Goncalves, J., Mendes, J., \& Resende, M. (2008, 9). A genetic algorithm for the resource constrained multiproject scheduling problem. European Journal of Operational Research, 189(3), 1171-1190.

Gutjahr, W., Strauss, C., \& Wagner, E. (2000, 3). A stochastic branch-and-bound approach to activity crashing in project management. Informs Journal on Computing, 12(2), 125-135.

Gutjahr, W. J., Katzensteiner, S., Reiter, P., Stummer, C., \& Denk, M. (2008). Competence-driven project portfolio selection, scheduling and staff assignment. Central European Journal of Operations Research, 16(3), 281-306.

Hartmann, S. (1998). A competitive genetic algorithm for resource-constrained project scheduling. Naval Research Logistics (NRL), 45(7), 733-750.

Hartmann, S. (2001). Project scheduling with multiple modes: A genetic algorithm. Annals of Operations Research, 102, 111-135.

Hartmann, D., De Strooper, B., Serneels, L., Craessaerts, K., Herreman, A., Annaert, W., ... \& Saftig, P. (2002). The disintegrin/metalloprotease ADAM 10 is essential for Notch signalling but not for $\alpha$-secretase activity in fibroblasts. Human Molecular Genetics, 11(21), 2615-2624.

Hartmann, S., \& Briskorn, D. (2010). A survey of variants and extensions of the resource-constrained project scheduling problem. European Journal of Operational Research, 207(1), 1-14.

Hegazy, T., \& Ersahin, T. $(2001,11)$. Simplified spreadsheet solutions. II: Overall schedule optimization. Journal of Construction Engineering and Management-ASCE, 127(6), 469-475. 
Heilmann, R. (2003, 1). A branch-and-bound procedure for the multi-mode resource-constrained project scheduling problem with minimum and maximum time lags. European Journal of Operational Research, 144(2), 348-365.

Heimerl, C., \& Kolisch, R. (2010). Scheduling and staffing multiple projects with a multi-skilled workforce. OR Spectrum, 32(2), 343-368.

Herroelen, W. (2005, 3). Project scheduling - Theory and practice. Production and Operations Management, 14(4), 413-432.

Herroelen, W., \& Leus, R. (2004, 4). Robust and reactive project scheduling: a review and classification of procedures. International Journal of Production Research, 42(8), 1599-1620.

Herroelen, W., \& Leus, R. (2004, 8). The construction of stable project baseline schedules. European Journal of Operational Research, 156(3), 550-565.

Herroelen, W., \& Leus, R. (2005, 9). Project scheduling under uncertainty: Survey and research potentials. European Journal of Operational Research, 165(2), 289-306.

Hoegl, M., Weinkauf, K., \& Gemuenden, H. G. (2004). Interteam coordination, project commitment, and teamwork in multiteam R\&D projects: A longitudinal study. Organization Science, 15(1), 38-55.

Hoegl, M., \& Parboteeah, K. (2007, 3). Creativity in innovative projects: How teamwork matters. Journal of Engineering and Technology Management, 24(1-2), 148-166.

Hoegl, M., \& Wagner, S. $(2005,8)$. Buyer-supplier collaboration in product development projects. Journal of Management, 31(4), 530-548.

Hoegl, M., Parboteeah, K., \& Gemuenden, H. (2003, 12). When teamwork really matters: task innovativeness as a moderator of the teamwork-performance relationship in software development projects. Journal of Engineering and Technology Management, 20(4), 281-302.

Huchzermeier, A., \& Loch, C. (2001, 1). Project management under risk: Using the real options approach to evaluate flexibility in R\&D. Management Science, 47(1), 85-101.

Hwang, B.-G., Zhao, X., \& Goh, K. $(2014,5)$. Investigating the client-related rework in building projects: The case of Singapore. International Journal of Project Management, 32(4), 698-708.

Hyari, K., \& El-Rayes, K. (2006, 1). Optimal planning and scheduling for repetitive construction projects. Journal of Management in Engineering, 22(1), 11-19.

Ibbs, C., Wong, C., \& Kwak, Y. (2001, 7). Project change management system. Journal of Management in Engineering, 17(3), 159-165.

Jarboui, B., Damak, N., Siarry, P., \& Rebai, A. (2008). A combinatorial particle swarm optimization for solving multi-mode resource-constrained project scheduling problems. Applied Mathematics and Computation, 195(1), 299-308.

Jergeas, G., \& Put, J. V. D. (2001). Benefits of constructability on construction projects. Journal of Construction Engineering and management, 127(4), 281-290.

Kaliba, C., Muya, M., \& Mumba, K. (2009, 7). Cost escalation and schedule delays in road construction projects in Zambia. International Journal of Project Management, 27(5), 522-531.

Karim, A., \& Adeli, H. (1999, 9). CONSCOM: An OO construction scheduling and change management system. Journal of Construction Engineering and Management-ASCE, 125(5), 368-376.

Karniel, A., \& Reich, Y. (2009, 11). From DSM-Based Planning to Design Process Simulation: A Review of Process Scheme Logic Verification Issues. IEEE Transactions on Engineering Management, 56(4), 636-649.

Kastor, A., \& Sirakoulis, K. (2009, 7). The effectiveness of resource levelling tools for Resource Constraint Project Scheduling Problem. International Journal of Project Management, 27(5), 493-500.

Ke, H., \& Liu, B. $(2005,9)$. Project scheduling problem with stochastic activity duration times. Applied Mathematics and Computation, 168(1), 342-353.

Ke, H., \& Liu, B. (2010, 2). Fuzzy project scheduling problem and its hybrid intelligent algorithm. Applied Mathematical Modelling, 34(2), 301-308.

Keil, M., Mann, J., \& Rai, A. (2000, 12). Why software projects escalate: An empirical analysis and test of four theoretical models. MIS Quaterly, 24(4), 631-664.

Keller, R. (2001, 6). Cross-functional project groups in research and new product development: Diversity, communications, job stress, and outcomes. Academy of Management Journal, 44(3), 547-555.

Keller, R. (2006, 1). Transformational leadership, initiating structure, and substitutes for leadership: A longitudinal study of research and development project team performance. Journal of Applied Psychology, 91(1), 202-210.

Klein, R. (2000, 12). Bidirectional planning: improving priority rule-based heuristics for scheduling resource-constrained projects. European Journal of Operational Research, 127(3), 619-638. 
Klein, R., \& Scholl, A. $(1999,1)$. Computing lower bounds by destructive improvement: An application to resource-constrained project scheduling. European Journal of Operational Research, 112(2), 322-346.

Kolisch, R., \& Padman, R. (2001, 6). An integrated survey of deterministic project scheduling. OMEGAInternational Journal of Management Science, 29(3), 249-272.

Kolisch, R., \& Hartmann, S. (2006). Experimental investigation of heuristics for resource-constrained project scheduling: An update. European Journal of Operational Research, 174(1), 23-37.

Kone, O., Artigues, C., Lopez, P., \& Mongeau, M. (2011, 1). Event-based MILP models for resourceconstrained project scheduling problems. Computers \& Operations Research, 38(1, SI), 3-13.

Koulinas, G., \& Anagnostopoulos, K. (2013, 5). A new tabu search-based hyper-heuristic algorithm for solving construction leveling problems with limited resource availabilities. Automation in Construction, $31,169-175$

Kuo, S., Merkley, G., \& Liu, C. (2000, 8). Decision support for irrigation project planning using a genetic algorithm. Agricultural Water Management, 45(3), 243-266.

Lambrechts, O., Demeulemeester, E., \& Herroelen, W. (2011, 6). Time slack-based techniques for robust project scheduling subject to resource uncertainty. Annals of Operations Research, 186(1), 443-464.

Lee, E., Park, Y., \& Shin, J. (2009, 4). Large engineering project risk management using a Bayesian belief network. Expert Systems with Application, 36(3), 5880-5887.

Levardy, V., \& Browning, T. (2009, 11). An Adaptive Process Model to Support Product Development Project Management. IEEE Transactions on Engineering Management, 56(4), 600-620.

Liberatore, M., Pollack-Johnson, B., \& Smith, C. (2001, 3). Project management in construction: Software use and research directions. Journal of Construction Engineering and Management-ASCE, 127(2), 101107.

Linberg, K. $(1999,12)$. Software developer perceptions about software project failure: a case study. Journal of Systems and Software, 49(2-3), 177-192.

Lipke, W., Zwikael, O., Henderson, K., \& Anbari, F. (2009, 5). Prediction of project outcome The application of statistical methods to earned value management and earned schedule performance indexes. International Journal of Project Management, 27(4), 400-407.

Liu, S.-S., \& Wang, C.-J. (2008, 11). Resource-constrained construction project scheduling model for profit maximization considering cash flow. Automation in Construction, 17(8), 966-974.

Lova, A., \& Tormos, P. (2001). Analysis of scheduling schemes and heuristic rules performance in resourceconstrained multiproject scheduling. Annals of Operations Research, 102, 263-286.

Love, P. (2002, 1). Influence of project type and costs in building procurement method on rework construction projects. Journal of Construction Engineering and Management-ASCE, 128(1), 18-29.

Love, P., Edwards, D., \& Irani, Z. (2008, 5). Forensic project management: An exploratory examination of the causal behavior of design-induced rework. IEEE Transactions on Engineering Management, 55(2), 234-247.

Love, P., Edwards, D., \& Irani, Z. (2012, 11). Moving Beyond Optimism Bias and Strategic Misrepresentation: An Explanation for Social Infrastructure Project Cost Overruns. IEEE Transactions on Engineering Management, 59(4), 560-571.

Love, P., Edwards, D., Smith, J., \& Walker, D. (2009, 11). Divergence or Congruence? A Path Model of Rework for Building and Civil Engineering Projects. Journal of Performance of Constructed Facilities, 23(6), 480-488.

Love, P., Liu, J., Matthews, J., Sing, C.-P., \& Smith, J. (2015, 8). Future proofing PPPs: Life-cycle performance measurement and Building Information Modelling. Automation in Construction, 56, 26-35.

Luu, V., Kim, S.-Y., Tuan, N., \& Ogunlana, S. (2009, 1). Quantifying schedule risk in construction projects using Bayesian belief networks. International Journal of Project Management, 27(1), 39-50.

Lyneis, J., Cooper, K., \& Els, S. (2001, 3). Strategic management of complex projects: a case study using system dynamics. System Dynamics Review, 17(3), 237-260.

Ma, Z., Shen, Q., \& Zhang, J. (2005, 6). Application of 4D for dynamic site layout and management of construction projects. Automation in Construction, 14(3, SI), 369-381.

McKoy, J. M., Angelotta, C., Bennett, C. L., Tallman, M. S., Wadleigh, M., Evens, A. M., ... \& DeAngelo, D. J. (2007). Gemtuzumab ozogamicin-associated sinusoidal obstructive syndrome (SOS): an overview from the research on adverse drug events and reports (RADAR) project. Leukemia Research, 31(5), 599604.

Mendes, J., Goncalves, J., \& Resende, M. (2009, 1). A random key based genetic algorithm for the resource constrained project scheduling problem. Computers \& Operations Research, 36(1, SI), 92-109.

Merkle, D., Middendorf, M., \& Schmeck, H. (2002). Ant colony optimization for resource-constrained project scheduling. IEEE transactions on evolutionary computation, 6(4), 333-346. 
Mika, M., Waligora, G., \& Weglarz, J. (2005, 8). Simulated annealing and tabu search for multi-mode resource-constrained project scheduling with positive discounted cash flows and different payment models. European Journal of Operational Research, 164(3), 639-668.

Mohring, R., Schulz, A., Stork, F., \& Uetz, M. (2003, 3). Solving project scheduling problems by minimum cut computations. Management Science, 49(3), 330-350.

Na, K.-S., Simpson, J., Li, X., \& Singh Tushar and Kim, K.-Y. (2007, 4). Software development risk and project performance measurement: Evidence in Korea. Journal of Systems and Software, 80(4, SI), 596605.

Neumann, K., \& Zimmermann, J. (1999, 9). Resource levelling for projects with schedule-dependent time windows. European Journal of Operational Research, 117(3), 591-605.

Neumann, K., \& Zimmermann, J. (2000, 12). Procedures for resource leveling and net present value problems in project scheduling with general temporal and resource constraints. European Journal of Operational Research, 127(2), 425-443.

Nightingale, P. $(2000,8)$. The product-process-organisation relationship in complex development projects. Research Policy, 29(7-8), 913-930.

Nitithamyong, P., \& Skibniewski, M. (2006, 1). Success/failure factors and performance measures of webbased construction project management systems: Professionals' viewpoint. Journal of Construction Engineering and Management, 132(1), 80-87.

Palpant, M., Artigues, C., \& Michelon, P. (2004). LSSPER: Solving the resource-constrained project scheduling problem with large neighbourhood search. Annals of Operations Research, 131(1-4), 237257.

Park, M., \& Pena-Mora, F. (2003, 3). Dynamic change management for construction: introducing the change cycle into model-based project management. System Dynamics Review, 19(3), 213-242.

Pena-Mora, F., \& Park, M. (2001, 11). Dynamic planning for fast-tracking building construction projects. Journal of Construction Engineering and Management-ASCE, 127(6), 445-456.

Popov, V., Juocevicius, V., Migilinskas, D., Ustinovichius, L., \& Mikalauskas, S. (2010, 5). The use of a virtual building design and construction model for developing an effective project concept in 5D environment. Automation in Construction, 19(3, SI), 357-367.

Ropponen, J., \& Lyytinen, K. (2000). Components of software development risk: How to address them? A project manager survey. IEEE Transactions on Software Engineering, 26(2), 98-112.

Pulley, J. M., Denny, J. C., Peterson, J. F., Bernard, G. R., Vnencak-Jones, C. L., Ramirez, A. H., ... \& Crawford, D. C. (2012). Operational implementation of prospective genotyping for personalized medicine: the design of the Vanderbilt PREDICT project. Clinical Pharmacology \& Therapeutics, 92(1), $87-95$.

Schwindt, C. (2006). Resource allocation in project management. Springer Science \& Business Media. Scott-Young, C., \& Samson, D. (2008, 11). Project success and project team management: Evidence from capital projects in the process industries. Journal of Operations Management, 26(6), 749-766.

Senouci, A., \& Adeli, H. $(2001,1)$. Resource scheduling using neural dynamics model of Adeli and Park. Journal of Construction Engineering and Management, 127(1), 28-34.

Smith, H., \& Keil, M. (2003, 1). The reluctance to report bad news on troubled software projects: a theoretical model. Information Systems Journal, 13(1), 69-95.

Sobel, M., Szmerekovsky, J., \& Tilson, V. (2009, 11). Scheduling projects with stochastic activity duration to maximize expected net present value. European Journal of Operational Research, 198(3), 697-705.

Tavares, L. V. (2002). A review of the contribution of operational research to project management. European Journal of Operational Research, 136(1), 1-18.

Tormos, P., \& Lova, A. (2001). A competitive heuristic solution technique for Resource-Constrained Project Scheduling. Annals of Operations Research, 102, 65-81.

Ulusoy, G., \& Cebelli, S. (2000, 12). An equitable approach to the payment scheduling problem in project management. European Journal of Operational Research, 127(2), 262-278.

Valls, V., Ballestin, F., \& Quintanilla, S. (2008, 3). A hybrid genetic algorithm for the resource-constrained project scheduling problem. European Journal of Operational Research, 185(2), 495-508.

Valls, V., Perez, A., \& Quintanilla, S. (2009, 3). Skilled workforce scheduling in Service Centres. European Journal of Operational Research, 193(3), 791-804.

Van De Vonder, S., Demeulemeester, E., Herroelen, W., \& Leus, R. (2006, 1). The trade-off between stability and makespan in resource-constrained project scheduling. International Journal of Production Research, 44(2), 215-236.

Vanhoucke, M., \& Vandevoorde, S. (2007, 10). A simulation and evaluation of earned value metrics to forecast the project duration. Journal of the Operational Research Society, 58(10), 1361-1374. 
Vanhoucke, M., Demeulemeester, E., \& Herroelen, W. (2001, 8). On maximizing the net present value of a project under renewable resource constraints. Management Science, 47(8), 1113-1121.

Viana, A., \& de Sousa, J. P. (2000). Using metaheuristics in multiobjective resource constrained project scheduling. European Journal of Operational Research, 120(2), 359-374.

Wang, H., Zhang, J., Chau, K., \& Anson, M. (2004, 9). 4D dynamic management for construction planning and resource utilization. Automation in Construction, 13(5), 575-589.

Wang, J., \& Lin, Y.-I. (2009, 9). An overlapping process model to assess schedule risk for new product development. Computers \& Industrial Engineering, 57(2, SI), 460-474.

Wang, M., \& Chou, H. (2003, 4). Risk allocation and risk handling of highway projects in Taiwan. Journal of Management in Engineering, 19(2), 60-68.

Wang, W.-C., Weng, S.-W., Wang, S.-H., \& Chen, C.-Y. (2014, 1). Integrating building information models with construction process simulations for project scheduling support. Automation in Construction, 37, 68-80.

Węglarz, J., Józefowska, J., Mika, M., \& Waligóra, G. (2011). Project scheduling with finite or infinite number of activity processing modes-A survey. European Journal of Operational Research, 208(3), 177205.

Yang, L.-R., Chen, J.-H., \& Wang, H.-W. (2012, 3). Assessing impacts of information technology on project success through knowledge management practice. Automation in Construction, 22(SI), 182-191.

Yamashita, D. S., Armentano, V. A., \& Laguna, M. (2006). Scatter search for project scheduling with resource availability cost. European Journal of Operational Research, 169(2), 623-637.

Zhang, H., Li, H., \& Tam, C. (2006, 3). Permutation-based particle swarm optimization for resourceconstrained project scheduling. Journal of Computing in Civil Engineering, 20(2), 141-149.

Zhang, S., Teizer, J., Pradhananga, N., \& Eastman, C. (2015, 12). Workforce location tracking to model, visualize and analyze workspace requirements in building information models for construction safety planning. Automation in Construction, 60, 74-86.

Zhao, X., Hwang, B.-G., \& Gao, Y. (2016, 3). A fuzzy synthetic evaluation approach for risk assessment: a case of Singapore's green projects. Journal of Cleaner Production, 115, 203-213.

Zhu, G., Bard, J., \& Yu, G. (2005, 4). Disruption management for resource-constrained project scheduling. Journal of the Operational Research Society, 56(4), 365-381.

Ziarati, K., Akbari, R., \& Zeighami, V. (2011). On the performance of bee algorithms for resourceconstrained project scheduling problem. Applied Soft Computing, 11(4), 3720-3733.

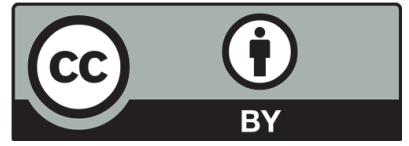

(C) 2019 by the authors; licensee Growing Science, Canada. This is an open access article distributed under the terms and conditions of the Creative Commons Attribution (CC-BY) license (http://creativecommons.org/licenses/by/4.0/). 